\title{
SUPERPOSIÇÃO DAS REGRAS DE TRANSIÇÃO NAS REFORMAS CONSTITUCIONAIS DA PREVIDÊNCIA SOCIAL BRASILEIRA
}

\author{
Marcelo Barroso Lima Brito de Campos ${ }^{1}$
}

\section{RESUMO:}

$\mathrm{O}$ artigo, mediante pesquisa bibliográfica e jurisprudencial, utilizando-se do método dedutivo, analisa quatro normas de transição das Emendas Constitucionais $n^{\circ} 20 / 98, n^{\circ} 41 / 03$ e $n^{\circ}$ $103 / 19$, que procederam a uma superposição normativa, majorando o pedágio de tempo do segurado de $20 \%$ para $50 \%$ no Regime Geral de Previdência Social e de 20\% para $100 \%$ no Regime Próprio de Previdência Social dos servidores públicos, incorrendo em inconstitucionalidade por ofensa aos postulados da segurança jurídica, segurança social, boafé, confiança legítima, direito expectado, proporcionalidade, razoabilidade e igualdade.

PALAVRAS-CHAVES: Superposição; regras de transição; previdência; reformas; constituição.

\section{SUPERPOSITION OF THE TRANSITION RULES IN THE CONSTITUTIONAL REFORMS OF BRAZILIAN SOCIAL SECURITY}

\begin{abstract}
:
The article, through bibliographic and jurisprudential research, using the deductive method, analyzes four transition rules of Constitutional Amendments $n^{\circ} .20 / 98, n^{\circ} .41 / 03$ and $n^{\circ}$. $103 / 19$, which proceeded to a normative superposition, increasing the insured time toll from $20 \%$ to $50 \%$ in the General Social Security Regime and from $20 \%$ to $100 \%$ in the Social Security Own Regime of civil servants, incurring unconstitutionality for offending the postulates of legal security, social security, good faith, legitimate expectations, expected rights, proportionality, reasonableness and equality.
\end{abstract}

KEYWORDS: Superposition; transitions rules; security; reforms; constitution

\section{INTRODUÇÃO}

Este artigo procedeu a investigação científica empregando a metodologia consistente na pesquisa bibliográfica e jurisprudencial, utilizando-se do método dedutivo.

\footnotetext{
1 Professor do Mestrado e da Graduação em Direito (Universidade Fumec). Pós-doutorando em Direito Tributário (UFMG). Doutor em Direito Público (PUCMinas). Mestre em Administração Pública (FJP). Procurador do Estado de Minas Gerais (AGE-MG). Associado Benemérito do Instituto Brasileiro de Direito Previdenciário (IBDP). Professor do Instituto de Estudos Previdenciários (IEPREV). Membro da Academia Brasileira de Direito da Seguridade Social (ABDSS). Advogado (OAB/MG). Presidente do Conselho Deliberativo (PREVCOM MG). Conselheiro Fiscal (OABPREV MG). Membro do Instituto dos Advogados de Minas Gerais (IAMG). Email: prof.marcelobarroso@yahoo.com.br.
} 
Nestes termos, percebeu-se que o Brasil implementou seu sistema de seguridade social com a promulgação da Constituição da República Federativa do Brasil (BRASIL, 1988), em cujo art. 194 a definiu como um conjunto integrado de ações de iniciativa dos poderes públicos e da sociedade destinados a assegurar benefícios e serviços nas áreas da saúde, assistência social e previdência social.

A previdência social brasileira é organizada em três regimes jurídicos ${ }^{2}$, a saber:

a) O Regime Geral de Previdência Social (RGPS);

b) O Regime Próprio de Previdência Social dos Servidores Públicos Titulares de Cargos Efetivos (RPPS);

c) O Regime de Previdência Complementar (RPC).

Estes regimes de previdência já foram objetos de reformas constitucionais e infraconstitucionais. No âmbito constitucional podem-se identificar as seguintes Emendas Constitucionais $n^{\circ} 3$ (BRASIL, 1993); $n^{\circ} 20$ (BRASIL, 1998); $n^{\circ} 41$ (BRASIL, 2003); $n^{\circ} 47$ (BRASIL, 2005); $\mathrm{n}^{\circ}$ 70, (BRASIL, 2012); $\mathrm{n}^{\circ} 88$ (BRASIL, 2015) e $\mathrm{n}^{\circ} 103$ (BRASIL, 2019).

A fim de proceder um corte epistemológico, destacam-se três emendas à constituição, que trouxeram no seu bojo normas de transição para a aposentadoria voluntária de segurados do Regime Geral de Previdência Social e de servidores do Regime Próprio de Previdência Social, que estavam em exercício quando de sua promulgação. São elas, as Emendas Constitucionais $n^{\circ} 20$ (BRASIL, 1998), $n^{\circ} 41$ (BRASIL, 2003) e $\mathrm{n}^{\circ} 103$ (BRASIL, 2019).

Neste ensaio serão analisadas quatro regras de transição das três emendas retro citadas e a superposição destas regras, bem como seu impacto no sistema constitucional brasileiro, com vistas a concluir pela constitucionalidade ou inconstitucionalidade das mesmas.

Para tanto, o artigo inicia seu desenvolvimento com os fundamentos constitucionais que servem de parâmetro para o controle de constitucionalidade, a fim de aferir se a superposição das normas de transição destacadas atendem à segurança (jurídica e social), à

\footnotetext{
${ }^{2}$ Poder-se-ia considerar um quarto regime, aquele que tem como destinatários os militares federais (Marinha, Exército e Aeronáutica) e estaduais (Polícias Militares e Corpos de Bombeiros Militares). Entretanto, a partir da Lei Federal $n^{\circ} 13.954$, de 2019, estes destinatários passam a ter um sistema de proteção social, diferente dos sistemas previdenciários existentes.
} 
boa-fé, a confiança legítima, o direito expectado, a proporcionalidade, a razoabilidade e a igualdade.

Em seguida apresenta-se a importância das regras de transição na condição de normas fundamentais da pessoa humana, com o objetivo de disciplinar adequadamente, no ajuste entre o passado e o futuro, a situação de segurados da previdência social que estejam em exercício, quando do implemento das reformas.

Ato contínuo, passa-se à análise do fenômeno da superposição das normas constitucionais de transição, observando-se a sua possibilidade e seus limites.

Ao final, será investigado se, os dispositivos constitucionais destacados, que regem o pedágio previdenciário ${ }^{3}$, são ou não constitucionais.

2 REFORMAS CONSTITUCIONAIS, SEGURANÇA (JURÍDICA E SOCIAL), BOAFÉ, PROPORCIONALIDADE, RAZOABILIDADE, CONFIANÇA LEGÍTIMA E DIREITO EXPECTADO: O NECESSÁRIO PONTO DE EQUILÍBRIO PARA A PREVIDÊNCIA SOCIAL

A credibilidade e a eficiência que se atribui a um sistema previdenciário é diretamente proporcional à segurança que ele confere aos seus segurados e dependentes. Com efeito, o beneficiário que se vincula ao um regime de previdência, ainda que de forma obrigatória, tem a expectativa legítima de que estará seguro em um momento de contingência.

Esta segurança não quer significar imutabilidade do sistema, eis que ajustes e reformas são necessários para a correção de distorções e melhoria na prestação dos benefícios e serviços previdenciários.

Nesse sentido, deve-se buscar a segurança na reforma, na mobilidade e no câmbio das normas jurídicas, sem prejudicar a credibilidade e a eficiência do sistema previdenciário. Por esse motivo, há que e conhecer melhor a segurança e as suas derivações. A segurança deriva para as modalidades jurídica, social, nacional e pública, destacando-se para fins do presente artigo as duas primeiras.

O autor deste artigo já teve a oportunidade de pontificar que:

\footnotetext{
${ }^{3}$ Entende-se por pedágio de previdenciário, o tempo a mais que o segurado deve trabalhar para completar o tempo de contribuição na regra de transição. Normalmente, se exige um percentual incidente sobre o tempo restante, que faltaria para completar 35 anos para homem ou 30 anos para mulher.
} 
A segurança jurídica transcende à ideia de certeza, legalidade, previsibilidade, regra, princípio, megaprincípio, subprincípio do Estado de Direito, valor, direito fundamental ou qualquer outro significado que deseje reduzir o seu alcance, visto que engloba todos eles, considerando tratar-se de condição de validade e de legitimidade no Estado Democrático de Direito. O preâmbulo da Constituição de 1988 já enuncia o postulado da segurança. (CAMPOS, 2012, p. 108)

$\mathrm{Na}$ verdade a segurança jurídica é um postulado para o Estado, para o Direito e para a Democracia, condição de validade e legitimidade dos mesmos, sendo declarada no art. $5^{\circ}$, caput da Constituição (BRASIL, 1988):

Art. $5^{\circ}$ Todos são iguais perante a lei, sem distinção de qualquer natureza, garantindo-se aos brasileiros e aos estrangeiros residentes no País a inviolabilidade do direito à vida, à liberdade, à igualdade, à segurança e à propriedade, nos termos seguintes:

A segurança social tem a mesma raiz da segurança jurídica, pois ambas advém do mesmo instituto. Considerando que se identificou a segurança jurídica como condição de validade e de legitimidade do Estado, do Direito e da Democracia, outra não é a solução, senão considerar a segurança social da mesma natureza. A segurança social está declarada no art. $6^{\circ}$, caput da Constituição (BRASIL, 1988):

Art. $6^{\circ}$ São direitos sociais a educação, a saúde, a alimentação, o trabalho, a moradia, o transporte, o lazer, a segurança, a previdência social, a proteção à maternidade e à infância, a assistência aos desamparados, na forma desta Constituição.

Nesse sentido, a segurança - jurídica e social - deve acobertar a relação jurídica previdenciária. Esta consiste no vínculo estabelecido entre o segurado/contribuinte e a Administração previdenciária, sobre a proteção dos riscos inerentes à atividade humana. 
Trata-se de uma relação longa, duradoura e de sucessivo trato, que deve ser protegida pela segurança.

A previsibilidade dos direitos sociais, especialmente das regras de aposentadoria, que possibilitam o planejamento do restante da vida das pessoas é uma medida de segurança jurídica e social. Desse modo, todas as vezes que as regras de aposentadoria se alteram podem e devem se alterar - também devem resguardar, não somente os direitos adquiridos, mas as situações em curso, especialmente aquelas que tem um alto grau de expectação.

O reforço da segurança jurídica e social está na boa-fé e na confiança legítima que marca a relação jurídica previdenciária. O segurado crê e confia no sistema e mesmo diante de alterações apresenta de boa-fé a confiança de que sua situação em curso será protegida contra alterações abruptas, injustas e desproporcionais.

Misabel Derzi (2006, p. 167) assevera que “é evidente que é necessário proteger a boa-fé e a confiança de quem tomou as suas decisões e pautou sua vida, acreditando nas promessas do legislador ou do administrador".

Lúcia Valle Figueiredo (FIGUEIREDO, 2003, p. 152) erige a boa fé a um princípio constitucional da Administração Pública, cuja previsão consta no art. 231, §6 $6^{\circ}$ da Constituição (BRASIL, 1988). Segundo a autora, a boa-fé é implícita ao princípio da moralidade de forma que a Administração Pública não pode agir de má-fé tendo que respeitar tal princípio.

Em outra passagem já se teve a oportunidade de destacar que:

Em Direito Previdenciário as expectativas de direitos não são simples, pois a cada dia, a cada minuto, a cada segundo, o segurado incorpora ao seu patrimônio, o tempo e as suas consequências, que a qualquer momento pode ser exigido como requisito de um benefício a ser concedido em decorrência de um sinistro. Portanto, em Direito Previdenciário melhor afirmar como Pontes de Miranda, posto que na relação jurídica previdenciária o que existem são direitos expectados. (CAMPOS, 2012, p. 114)

Pontes de Miranda (1955, p. 282) entende que seria um erro "se tratássemos como sendo no mesmo plano todas as expectativas". Por isso, esse autor propõe a diferenciação entre as meras expectativas e os direitos expectados, aquelas simples pretensões, ou sombras, como ele as denominam, e esses, direito a adquirir direitos. 
Portanto, em Direito Previdenciário melhor afirmar como Pontes de Miranda, posto que na relação jurídica previdenciária o que existem são direitos expectados, consistentes naqueles que, a despeito de não serem ainda adquiridos, também não são meras expectativas, eis que se trata do tempo decorrido e incorporado ao patrimônio jurídico do segurado.

Os princípios da proporcionalidade e da razoabilidade, reforçam ainda mais essa constelação de fundamentos constitucionais. O marco teórico adotado para definir tais princípios é a doutrina sustentada de Robert Alexy (1993), para quem o princípio da proporcionalidade deve atender à tríade da necessidade, adequação e proporcionalidade em sentido estrito (eficiência), enquanto que o princípio da razoabilidade deve aferir o ato em seu ambiente externo e interno.

A proteção da segurança - jurídica e social -, a boa-fé, a confiança legítima, o direito expectado, a proporcionalidade e a razoabilidade serão atendidas na medida em que as reformas constitucionais não os agredirem.

Quando as alterações assegurarem a necessária proteção do tempo decorrido, não somente em relação ao direito adquirido, mas também aos direitos expectados, haverá a proteção dos postulados mencionados.

O tempo decorrido, em que o segurado já tenha realizado um trabalho e efetuado contribuições previdenciárias para o sistema, em que pese ainda não alcançar, por exemplo, uma modalidade de aposentadoria, não pode ser desconsiderado, eis que exige proteção.

Ainda que não sejam princípios expressos de maneira geral na Constituição (BRASIL, 1988), os princípios da proporcionalidade e da razoabilidade já sedimentaram sua pertinência ao bloco de constitucionalidade brasileiro, eis ser fato notório a expressa utilização dele pelo Supremo Tribunal Federal ${ }^{4}$, razão por que podem e devem ser parâmetro de controle de constitucionalidade.

Por isso, se as mudanças na previdência social são necessárias e devem ser implementadas por meio de reformas constitucionais, então que encontrem um ponto de equilíbrio para proteger a segurança (jurídica e social), a boa-fé e a confiança legítima de

\footnotetext{
${ }^{4}$ Exemplos de julgados em que o Supremo Tribunal Federal utilizou os princípios da proporcionalidade e da razoabilidade, como parâmetro constitucional para decidir em sede de controle concentrado: ADI 1724 (BRASIL, 2019 a ), ADI 907 (BRASIL, 2017 a) e ADI 5468 (BRASIL, 2017 b). E, em sede de controle difuso: RE 958252 (BRASIL, 2019 b), HC 124.306 (BRASIL, 2016 a) e RE 778889 (BRASIL, 2016 b), dentre inúmeros outros.
} 
maneira proporcional e razoável, mediante a proteção não somente do direito adquirido, mas também dos direitos expectados.

Neste contexto, o papel das normas de transição é fundamental. A capacidade que as normas de transição conferem à proteção da segurança jurídica e social, da boa-fé, da confiança legítima e do direito expectado, que irá mensurar a manutenção, o recrudescimento ou o declínio da credibilidade e da eficiência de um sistema previdenciário alterado.

\title{
3 ENTRE O PASSADO E O FUTURO: AS NORMAS DE TRANSIÇÃO
}

Em termos retrospectivos, a nova norma não pode retroagir para prejudicar seus destinatários, pois deve proteger os direitos adquiridos e ajustar, de modo seguro, os direitos expectados (o tempo já realizado), por isso as regras de transição.

Mais uma vez segue o escólio de Misabel Derzi (2006, p. 200):

\begin{abstract}
Em lugar da bipolaridade radical - direitos adquiridos, que seriam inatingíveis pelo direito novo, opostos às meras expectativas de direito, totalmente desprotegidas contra as inovações - as Cortes de Justiça dos países mais desenvolvidos, em especial a européia e a Corte Constitucional Alemã, inseriram definitivamente um terceiro ponto mediano, os direitos de transição, como direito fundamental. A Justiça prospectiva pode designar assim tanto os direitos de transição, como mecanismos impostos ao legislador, ao juiz ou ao administrador, garantidores da previsibilidade do direito.
\end{abstract}

Como se vê, as normas de transição não são benesses do legislador reformista. Tratase de verdadeiro direito fundamental da pessoa humana à segurança jurídica e social, bem como seu reforço da confiança legítima e da boa-fé.

A ausência de normas de transição ou mesmo as normas de transição que não alcançam todas as situações acarreta inconstitucionalidade por omissão.

Com efeito, a inexistência de normas de transição significa um completo desrespeito e ausente proteção às situações em curso, ainda não consolidadas na ótica da nova lei e, em consequência, causa insegurança e abala a boa-fé e a confiança legítima que os segurados da previdência depositam em seus respectivos sistemas previdenciários. 
Regras de transição incompletas, que apenas registram formalmente a sua existência, mas não colhem todas as situações em desenvolvimento, quando do advento da nova lei, igualmente não atende aos ditames da segurança, da boa-fé e da confiança legítima.

Em análise do julgado da Ação Direta de Inconstitucionalidade n 3105 (BRASIL, 2007) do Supremo Tribunal Federal, já enunciamos que:

Há quem diga que a ausência de normas de transição significa omissão legislativa inconstitucional, como fez o Ministro do Supremo Tribunal Federal Gilmar Mendes em seu voto proferido no julgamento da Ação Direta de Inconstitucionalidade 3.105. A omissão quanto às normas de transição são extremamente prejudiciais ao Estado e ao Direito, não só pela ausência dos critérios normativos definidos, mas também pela possibilidade do Estado responder patrimonialmente em face da omissão normativa. (CAMPOS, 2012, p. 122)

Aliado a tudo isso, não se pode desconsiderar que o tempo decorrido, exercido e com contribuição por parte do segurado, já se incorporou ao seu patrimônio e, como tal, deve ser protegido pelo direito de propriedade, conforme art. $5^{\circ}$, caput e inciso XXII da Constituição (BRASIL, 1988). O cumprimento da função social desse direito, nos termos do, art. $5^{\circ}$, inciso XXIII, da Constituição (BRASIL, 1988) consiste na sua proteção. Nesse sentido, o tempo decorrido é um direito expectado de natureza patrimonial e social.

As normas de transição são absolutamente necessárias para acomodar as situações que estejam em fase de formação, por ocasião do surgimento do novo ordenamento promovido pela alteração legislativa. Essa acomodação deve ocorrer de modo proporcional e razoável, evitando-se surpresas e abusos na desproteção dos direitos expectados.

\section{A SUPERPOSIÇÃO DAS NORMAS DE TRANSIÇÃO NAS REFORMAS CONSTITUCIONAIS}

Na sucessão de normas constitucionais de transição, não se trata de uma simples substituição, em que se troca a norma anterior pela nova norma. A substituição de normas tem um efeito prospectivo, eis que a nova norma deve reger situações doravante à existência dela, não tendo havido regência das situações retrospectivas. Isso não é possível em regras de transição, que tem como objetivo disciplinar situações anteriores, com efeitos prospectivos. 
Então, quando se trata de sucessão de normas constitucionais de transição, na verdade, o que ocorre é uma superposição de normas, porquanto as normas de transição anteriores regeram as mesmas situações retrospectivas, que serão regidas pela nova norma de transição, com efeitos prospectivos.

A compreensão do vocábulo "superposição" é importante para entender o procedimento ocorrido nas reformas constitucionais da previdência social brasileira. Segundo Aurélio Buarque de Holanda Ferreira (2010, p. 705) superpor ou sobrepor significa "1. pôr em cima ou por cima. 2. Considerar com preferência. 3. Pôr-se ou colocar-se sobre, acima."

Assim, com o objetivo de tratar das situações em curso, ainda não consolidadas e em formação na égide da legislação anterior, a nova norma de transição será superposta, colocada em cima da norma de transição anterior para tratar das mesmas situações. Por evidente, a nova norma de transição, nesse procedimento de superposição, revoga a norma de transição anterior, por disciplinar a mesma situação, como determina o art. $2^{\circ}$, caput e seu $\S 1^{\circ}$, da Lei de Introdução às normas do Direito Brasileiro - LINDB (BRASIL, 1942).

Com relação à possibilidade de superposição de normas constitucionais de transição, inexiste no Ordenamento Jurídico brasileiro, qualquer legislação que a vede, sendo, pois, juridicamente viável. Impedir a alteração de uma das principais fontes do Direito - lei criando empecilho para que se amolde as normas aos fatos presentes e projeções futuras constitui um engessamento indevido e contrário aos princípio democráticos e republicanos, conforme art. $1^{\circ}$ da Constituição (BRASIL, 1988).

Entretanto, essa superposição, a despeito de ser possível, encontra limites, justamente na segurança (jurídica e social), na boa-fé e na confiança legítima.

Nesse cenário é que se propõe investigar o efeito causado pela superposição das normas de transição nas reformas constitucionais da previdência social brasileira, para saber se o modo em que foi feita, está em sintonia com a proteção da segurança (jurídica e social), da boa-fé e da confiança legítima. Para tanto, serão analisados dois pontos a serem destacados da reforma, para desenvolvimento do raciocínio a ser trabalhado neste artigo.

\section{DESTAQUES DAS REGRAS DE TRANSISÇÃO SUPERPOSTAS NAS REFORMAS CONSTITUCIONAIS DA PREVIDÊNCIA SOCIAL BRASILEIRA}


Destacam-se, para o estudo, as seguintes superposições de normas de transição, no que se referem aos requisitos para a aposentadoria voluntária, ocorridas com o advento da Emenda Constitucional n 103 (BRASIL, 2019):

a) No Regime Geral de Previdência Social (RGPS): O inciso II, do art. 35 da Emenda Constitucional $\mathrm{n}^{\circ} 103$ (BRASIL, 2019) revogou o art. 9०, da Emenda Constitucional $\mathrm{n}^{\circ} 20$ (BRASIL, 1998) e superpôs a ele o art. 17, da Emenda Constitucional $\mathrm{n}^{\circ} 103$ (BRASIL, 2019);

b) No Regime Próprio de Previdência Social dos Servidores Públicos (RPPS): O inciso III, do art. 35 da Emenda Constitucional n ${ }^{\circ} 103$ (BRASIL, 2019) revogou o art. $2^{\circ}$ da Emenda Constitucional $\mathrm{n}^{\circ} 41$ (BRASIL, 2003) e superpôs a ele o art. 20, da Emenda Constitucional $\mathrm{n}^{\circ} 103$ (BRASIL, 2019); ${ }^{5}$

Evidencia-se a necessidade de compreender os textos das regras de transição revogados e superpostos.

Em relação aos segurados do Regime Geral de Previdência Social, o art. $9^{\circ}$, da Emenda Constitucional n 20 (BRASIL, 1998), tinha a seguinte redação:

\footnotetext{
Art. $9^{\circ}$ - Observado o disposto no art. $4^{\circ}$ desta Emenda e ressalvado o direito de opção a aposentadoria pelas normas por ela estabelecidas para o regime geral de previdência social, é assegurado o direito à aposentadoria ao segurado que se tenha filiado ao regime geral de previdência social, até a data de publicação desta Emenda, quando, cumulativamente, atender aos seguintes requisitos: (Revogado pela Emenda Constitucional $\mathrm{n}^{\circ} 103$, de 2019)

I - contar com cinqüenta e três anos de idade, se homem, e quarenta e oito anos de idade, se mulher; e (Revogado pela Emenda Constitucional no 103, de 2019)

II - contar tempo de contribuição igual, no mínimo, à soma de: (Revogado pela Emenda Constitucional n ${ }^{\circ} 103$, de 2019)

a) trinta e cinco anos, se homem, e trinta anos, se mulher; e (Revogado pela Emenda Constitucional $\mathrm{n}^{\circ} 103$, de 2019)

b) um período adicional de contribuição equivalente a vinte por cento do tempo que, na data da publicação desta Emenda, faltaria para atingir o limite de tempo constante da alínea anterior.
}

\footnotetext{
${ }^{5}$ Importante observar nesse caso que "ficam imediatamente revogadas para os servidores federais as regras de transição dos arts. $2^{\circ}, 6^{\circ}, 6^{\circ}$-A da EC n. 41/2003 e art. $3^{\circ}$ da EC n. 47/2005. Com relação aos servidores estaduais, distritais e municipais, depende de lei da unidade federativa que realize a reforma previdenciária no seu âmbito, restando mantida, portanto, as regras de transição das EC n. 41/2003 e n. 47/2005 (EC n. 103/2019, art. 35, III e IV, c/c art. 36, II)". (CAMPOS, 2010, p. 178)
} 
Observa-se na regra de transição constante do então art. $9^{\circ}$, da Emenda Constitucional $\mathrm{n}^{\circ} 20$ (BRASIL, 1998), a alínea b, do inciso II, que, em proteção ao direito expectado consistente no tempo decorrido, exigiu o cumprimento do denominado pedágio, que é um período adicional de tempo de contribuição equivalente a $20 \%$ do tempo que, na data da publicação da Emenda Constitucional n 20 (BRASIL, 1998), faltaria para atingir o limite de tempo de 35 anos de contribuição para homens e 30 para mulher.

O percentual acrescido de $20 \%$ é um período de tempo razoável, que acomoda com segurança, prestígio à boa-fé e confiança legítima, a situação daqueles segurados do Regime Geral de Previdência Social que estavam ativos no momento da promulgação da Emenda Constitucional $\mathrm{n}^{\circ} 20$ (BRASIL, 1998).

Ocorre que, em superposição de normas de transição, a Emenda Constitucional $\mathrm{n}^{\circ}$ 103 (BRASIL, 2019), colocou acima do referido art. $9^{\circ}$, da Emenda Constitucional $\mathrm{n}^{\circ} 20$ (BRASIL, 1998), o disposto no art. 17, da própria Emenda Constitucional n 103 (BRASIL, 2019), que assim determina:

Art. 17. Ao segurado filiado ao Regime Geral de Previdência Social até a data de entrada em vigor desta Emenda Constitucional e que na referida data contar com mais de 28 (vinte e oito) anos de contribuição, se mulher, e 33 (trinta e três) anos de contribuição, se homem, fica assegurado o direito à aposentadoria quando preencher, cumulativamente, os seguintes requisitos:

I - 30 (trinta) anos de contribuição, se mulher, e 35 (trinta e cinco) anos de contribuição, se homem; e

II - cumprimento de período adicional correspondente a $50 \%$ (cinquenta por cento) do tempo que, na data de entrada em vigor desta Emenda Constitucional, faltaria para atingir 30 (trinta) anos de contribuição, se mulher, e 35 (trinta e cinco) anos de contribuição, se homem.

Verifica-se no inciso II, do art. 17, da Emenda Constitucional n ${ }^{\circ} 103$ (BRASIL, 2019), que o pedágio passou dos $20 \%$ do tempo que, na data da publicação da emenda, faltaria para atingir o limite de tempo de 35 anos de contribuição para homens e 30 anos de contribuição para mulher, conforme previa o art. $9^{\circ}$, da Emenda Constitucional $\mathrm{n}^{\circ} 20$ (BRASIL, 1998), para 50\% deste tempo. Esse aumento do pedágio de $20 \%$ para 50\%, representa um acréscimo de $150 \%$ do tempo que era exigido. 
Nestes termos o segurado do Regime Geral de Previdência Social terá que trabalhar mais de uma vez e meia o tempo que teria que trabalhar se comparado com a regra de transição anterior.

No âmbito do Regime Próprio de Previdência dos Servidores Públicos a alteração foi ainda mais drástica.

Com efeito, dispunha o art. $2^{\circ}$, da Emenda Constitucional $n^{\circ} 41$ (BRASIL, 2003), disciplinando a situação do servidor titular de cargo efetivo, segurado do Regime Próprio de Previdência Social:

\footnotetext{
Art. $2^{\circ}$ Observado o disposto no art. $4^{\circ}$ da Emenda Constitucional $n^{\circ} 20$, de 15 de dezembro de 1998, é assegurado o direito de opção pela aposentadoria voluntária com proventos calculados de acordo com o art. 40 , $\S \S 3^{\circ}$ e 17 , da Constituição Federal, àquele que tenha ingressado regularmente em cargo efetivo na Administração Pública direta, autárquica e fundacional, até a data de publicação daquela Emenda, quando o servidor, cumulativamente:

I - tiver cinqüenta e três anos de idade, se homem, e quarenta e oito anos de idade, se mulher;

II - tiver cinco anos de efetivo exercício no cargo em que se der a aposentadoria;

III - contar tempo de contribuição igual, no mínimo, à soma de:

a) trinta e cinco anos, se homem, e trinta anos, se mulher; e

b) um período adicional de contribuição equivalente a vinte por cento do tempo que, na data de publicação daquela Emenda, faltaria para atingir o limite de tempo constante da alínea $a$ deste inciso.
}

Como se vê, na regra de transição prevista no então art. $2^{\circ}$, da Emenda Constitucional $n^{\circ} 41$ (BRASIL, 2003), destaca-se a alínea b, do inciso III, que, em proteção ao direito expectado consistente no tempo decorrido, exigiu também para os servidores públicos pertencentes ao Regime Próprio de Previdência Social, o cumprimento de pedágio, consistente em um período adicional de tempo de contribuição equivalente a $20 \%$ do tempo que, na data da publicação da Emenda Constitucional n 20 (BRASIL, 1998), faltaria para atingir o limite de tempo de 35 anos de contribuição para homens e 30 para mulher.

Percebe-se que houve isonomia de tratamento, em relação às situações semelhantes para o segurado do Regime Geral de Previdência Social.

De fato, o percentual acrescido de $20 \%$ é um período de tempo razoável, que acomoda com segurança, prestígio à boa-fé e confiança legítima, a situação daqueles 
segurados servidores públicos do Regime Próprio de Previdência Social que estavam ativos no momento da promulgação da Emenda Constitucional nº 20 (BRASIL, 1998).

Em sede de superposição normativa das regras constitucionais de transição, o art. 20, da Emenda Constitucional $n^{\circ} 103$ (BRASIL, 2019), foi colocado acima da revogada norma do art. $2^{\circ}$, da Emenda Constitucional n ${ }^{\circ} 41$ (BRASIL, 2003), com a seguinte redação:

\footnotetext{
Art. 20. O segurado ou o servidor público federal que se tenha filiado ao Regime Geral de Previdência Social ou ingressado no serviço público em cargo efetivo até a data de entrada em vigor desta Emenda Constitucional poderá aposentar-se voluntariamente quando preencher, cumulativamente, os seguintes requisitos:

I - 57 (cinquenta e sete) anos de idade, se mulher, e 60 (sessenta) anos de idade, se homem;

II - 30 (trinta) anos de contribuição, se mulher, e 35 (trinta e cinco) anos de contribuição, se homem;

III - para os servidores públicos, 20 (vinte) anos de efetivo exercício no serviço público e 5 (cinco) anos no cargo efetivo em que se der a aposentadoria;

IV - período adicional de contribuição correspondente ao tempo que, na data de entrada em vigor desta Emenda Constitucional, faltaria para atingir o tempo mínimo de contribuição referido no inciso II.
}

Evidencia-se do inciso IV, do art. 20, da Emenda Constitucional n ${ }^{\circ} 103$ (BRASIL, 2019), que se passa a exigir do servidor público titular de cargo efetivo vinculado ao Regime Próprio de Previdência Social, um pedágio de $100 \%$ do tempo que, na data da publicação da Emenda Constitucional n ${ }^{\circ} 20$ (BRASIL, 1998), faltaria para atingir o limite de tempo de 35 anos de contribuição para homens e 30 anos de contribuição para mulher, contra os $20 \%$ que eram exigidos pelo art. $2^{\circ}$, III, b, da Emenda Constitucional n 41 (BRASIL, 2003).

Neste caso a exigência quintuplicou. Assim, para se aposentar nessa regra o servidor deverá trabalhar cinco vezes mais o tempo que lhe era necessário realizar, se vigente a regra anterior.

Constatados estes fatos, algumas conclusões podem ser deles extraídas.

Uma conclusão possível consiste em perceber o exagero dos percentuais exigidos a título de pedágio, tanto para o segurado do Regime Geral de Previdência Social (50\%), quanto para o segurado servidor do Regime Próprio de Previdência Social (100\%). 
Com efeito, os novos percentuais fixados pelas regras de transição advindas da Emenda Constitucional $\mathrm{n}^{\circ} 103$ (BRASIL, 2019) são desproporcionais e irrazoáveis em relação a dois aspectos, a saber:

a) quanto aos percentuais antes praticados no âmbito da previdência social; e

b) quanto aos outros percentuais aplicados no Ordenamento Jurídico brasileiro, como um todo.

No que se refere ao primeiro aspecto, já se ponderou neste artigo que os percentuais de 50\% utilizados pela nova regra para o Regime Geral de Previdência Social, consiste em exigir do segurado que trabalhe e contribua uma vez e meia (ou 150\%) há mais daquele tempo que teria que trabalhar em comparação com o sistema anterior, ou seja, mais que o dobro do que deveria laborar e contribuir.

Situação mais gravosa ocorre no Regime Próprio de Previdência Social em que o servidor deve continuar ativo e contribuindo por cinco vezes mais de tempo do que aquele que teria que laborar se vigente a norma anterior. Nessa relação, fica evidente o exagero dos novos percentuais, tanto no Regime Geral de Previdência Social, quanto no Regime Próprio de Previdência Social, que exigem tempo absolutamente desproporcional e irrazoável, se comparado ao sistema anterior.

No que tange ao segundo aspecto, é importante investigar e demonstrar que a Ordem Jurídica brasileira rechaça, em sede de sua jurisprudência, percentuais acima de $20 \%$ em outros ramos do Direito, que serve de parâmetro analógico para considerar exagerado o pedágio acima deste patamar.

É o que ocorre, por exemplo, com a multa isolada em matéria tributária. Sabe-se que além da multa incidente sobre o valor do tributo devido, aplicável quando este não for adimplido a tempo e modo, ou seja, aplicado quando não houver cumprimento da obrigação tributária principal, também existe a chamada multa isolada, consistente naquele encargo devido pelo sujeito passivo por descumprimento de obrigação tributária secundária ou acessória. Vários entes federados preveem em sua legislação, multas de percentuais variados, acima de $40 \%$, chegando em alguns casos a 100 ou 200\% do valor do tributo devido. Esses percentuais são questionados, porquanto estariam praticando o vedado confisco.

O Supremo Tribunal Federal reconheceu repercussão geral no tema 487, que trata do "caráter confiscatório da "multa isolada" por descumprimento de obrigação acessória 
decorrente de dever instrumental. O leading case consubstanciado no RE 640452 (BRASIL, 2011), da Relatoria do Ministro Roberto Barroso discute, à luz do artigo 150, IV, da Constituição Federal de 1988, se multa por descumprimento de obrigação acessória decorrente de dever instrumental, aplicada em valor variável entre 5\% a 40\%, relacionado à operação que não gerou crédito tributário ("multa isolada") possui caráter confiscatório.

Veja que o limite máximo definido é de $40 \%$, eis que por razões evidentes o percentual acima deste patamar configura confisco. A discussão então, que está pendente de fixação da tese, está em se definir qual percentual abaixo dos $40 \%$ seria razoável e proporcional. Eis a ementa do julgado paradigma:

CONSTITUCIONAL. TRIBUTÁRIO. PUNIÇÃO APLICADA PELO DESCUMPRIMENTO DE OBRIGAÇÃO ACESSÓRIA. DEVER INSTRUMENTAL RELACIONADO À OPERAÇÃO INDIFERENTE AO VALOR DE DÍVIDA TRIBUTÁRIA (PUNIÇÃO INDEPENDENTE DE TRIBUTO DEVIDO). "MULTA ISOLADA". CARÁTER CONFISCATÓRIO. PROPORCIONALIDADE. RAZOABILIDADE. QUADRO FÁTICO-JURÍDICO ESPECÍFICO. PROPOSTA PELA EXISTÊNCIA DA REPERCUSSÃO GERAL DA MATÉRIA CONSTITUCIONAL DEBATIDA. Proposta pelo reconhecimento da repercussão geral da discussão sobre o caráter confiscatório, desproporcional e irracional de multa em valor variável entre $40 \%$ e $05 \%$, aplicada à operação que não gerou débito tributário. (BRASIL, 2011)

Dispõe o art. 150, IV, da Constituição (BRASIL, 1988):

Art. 150. Sem prejuízo de outras garantias asseguradas ao contribuinte, é vedado à União, aos Estados, ao4e Distrito Federal e aos Municípios:

[...]

IV - utilizar tributo com efeito de confisco;

Com relação ao mencionado dispositivo constitucional e às multas isoladas, o Supremo Tribunal Federal já proferiu os seguintes entendimentos:

EMENTA: AGRAVO REGIMENTAL NO AGRAVO DE INSTRUMENTO. TRIBUTÁRIO. MULTA MORATÓRIA DE 30\%. CARÁTER CONFISCATÓRIO

Rev. de Direitos Sociais, Seguridade e Previdência Social | e-ISSN: 2525-9865 | Evento Virtual | v. 6 | n. 1 | p. 101-122 | Jan/Jun. 2020 
RECONHECIDO. INTERPRETAÇÃO DO PRINCÍPIO DO NÃO CONFISCO À LUZ DA ESPÉCIE DE MULTA. REDUÇÃO PARA 20\% NOS TERMOS DA JURISPRUDÊNCIA DA CORTE. 1. É possível realizar uma dosimetria do conteúdo da vedação ao confisco à luz da espécie de multa aplicada no caso concreto. 2. Considerando que as multas moratórias constituem um mero desestímulo ao adimplemento tardio da obrigação tributária, nos termos da jurisprudência da Corte, é razoável a fixação do patamar de $20 \%$ do valor da obrigação principal. 3. Agravo regimental parcialmente provido para reduzir a multa ao patamar de $20 \%$. (BRASIL, 2015a)

AGRAVO REGIMENTAL EM RECURSO EXTRAORDINÁRIO. TRIBUTÁRIO. VEDAÇÃO AO CONFISCO. MULTA MORATÓRIA. ADOÇÃO DO LIMITE OBJETIVO DE 20\%. 1. Não merece reparo o acórdão regional que mantém o valor da multa moratória ao patamar de $20 \%$. Trata-se de montante que se coaduna com a ideia de que a impontualidade é uma falta menos grave que a violação à legislação tributária. 2. Agravo regimental a que se nega provimento. (BRASIL, 2015b)

Portanto, o Supremo Tribunal Federal, até o presente momento conduz ao entendimento de que a fixação não confiscatória estaria no patamar abaixo de 40\%, sugerindo o percentual de $20 \%$ nos julgados proferidos. Nessa senda, o percentual de $50 \%$ (para o Regime Geral de Previdência Social) e 100\% (para o Regime Próprio de Previdência Social) a título de pedágio, em sede de analogia jurídica, seria aquele, pouco acima do limite e este, absurdamente acima do percentual tolerável como proporcional e razoável.

No âmbito do Direito Civil a multa considerada razoável e proporcional é de $10 \%$ e no Direito do Consumidor é de $2 \%$. O Superior Tribunal de Justiça, no julgamento do Recurso Especial n 1.424.814-SP, Rel. Min. Marco Aurélio Bellizze, julgado em 4/10/2016 e publicado do Diário de Justiça Eletrônico (DJe) 10/10/2016, resume muito bem a situação:

[...] a multa contratual, concebida como espécie de cláusula penal (no caso, cláusula penal moratória), assume um nítido viés coercitivo e punitivo, na medida em que as partes, segundo o princípio da autonomia privada, convencionam a imposição de uma penalidade na hipótese de descumprimento da obrigação, cujo limite, nos contratos civis, é de $10 \%$ sobre o valor da dívida (arts. $8^{\circ}$ e $9^{\circ}$ do Decreto $n$. 22.626/1933); nas dívidas condominiais, de $2 \%$ (art. $1.336, \S 1^{\circ}$, do CC); e nos contratos de consumo, de $2 \%$. (BRASIL, 2016c)

No âmbito do Direito do Consumidor, o Superior Tribunal de Justiça já julgou em Recurso Repetitivo, $\mathrm{n}^{\circ}$ 1063343, Tema 52, que "multa contratual (deve ser) limitada a $2 \%$ do valor da prestação, nos termos do art. 52, § 1º, do CDC.” (BRASIL, 2010). 
Ora, se o limite da multa no Direito Tributário é no máximo 20\%, no Direito Civil $10 \%$, no Direito Condominial $2 \%$ e no Direito do Consumidor é $2 \%$, quando se trata de cláusula penal, objetivando punir o infrator, pela inadimplência, porque no Direito Previdenciário o pedágio, que não tem caráter punitivo e tem por finalidade proteger um direito social patrimonial expectado, tem que ser de 50 a 100\%? Não há lógica.

Fica evidenciado o exagero, a falta de proporção, ausente razoabilidade, ofensa à segurança (jurídica e social), à boa-fé e à confiança legítima dos percentuais empregados na reforma constitucional da previdência social. Em consequência as superposições de normas constitucionais de transição na reforma da previdência social, especificamente do art. 17 da Emenda Constitucional $\mathrm{n}^{\circ} 103$ (BRASIL, 2019) sobre o art. $9^{\circ}$, da Emenda Constitucional $\mathrm{n}^{\circ}$ 20 (BRASIL, 1998) e do art. 20, da Emenda Constitucional n 103 (BRASIL, 2019) sobre o art. $2^{\circ}$, da Emenda Constitucional n ${ }^{\circ} 41$ (BRASIL, 2003), são nitidamente inconstitucionais.

Outra conclusão a que se chega é a de que houve uma discriminação negativa e inconstitucional, no tratamento previdenciário dispensado em relação aos segurados do Regime Geral de Previdência Social e aos servidores segurados do Regime Próprio de Previdência Social.

$\mathrm{Na}$ égide das Emendas Constitucionais n 20 (BRASIL, 1998) e $n^{\circ} 41$ (BRASIL, 2003), não havia tratamento desigual entre segurados dos Regime Geral de Previdência Social e segurados servidores do Regime Próprio de Previdência Social, pois em relação a ambos era exigido o pedágio igual, de $20 \%$ do tempo que, na data da publicação da Emenda Constitucional $\mathrm{n}^{\circ} 20$ (BRASIL, 1998), faltaria para atingir o limite de tempo de 35 anos de contribuição para homens e 30 anos de contribuição para mulher. Justo, seguro, confiável, proporcional e razoável, foi o tratamento igual, fundamentado na isonomia ou igualdade formal a que se refere o art. $5^{\circ}$, caput, da Constituição (BRASIL, 1988) pois todos são iguais sem distinção de qualquer natureza.

Saliente-se que naquele momento não se vislumbrou qualquer situação que exigisse tratamento desigual, para aplicar a versão material da igualdade.

Ocorre que, a Emenda Constitucional $\mathrm{n}^{\circ} 103$ (BRASIL, 2019), sem qualquer justificativa ou fundamento, estabeleceu, doravante, um discrímen dos servidores segurados do Regime Próprio de Previdência Social em relação aos segurados do Regime Geral de Previdência Social. Dessa forma impôs pedágios diferentes - 50\% no Regime Geral de 
Previdência Social e 100\% no Regime Próprio de Previdência Social - , criando uma discriminação negativa e inconstitucional em flagrante ofensa ao art. $3^{\circ}, \mathrm{IV} \mathrm{c} / \mathrm{c}$ art. $5^{\circ}$, caput, ambos da Constituição (BRASIL, 1988) ${ }^{6}$.

Fica claro e inconteste de dúvidas que tal alteração normativa advinda da superposição de regras constitucionais de transição abala a confiança que o segurado legitimamente e de boa-fé deposita no sistema previdenciário, esperando que nas alterações normativas haja um tratamento isonômico ou, quando necessária a discriminação positiva, que seja fundamentada e justificada, o que não ocorreu no presente caso. Por conseguinte, essa superposição não alcança o desejo constitucionalmente assegurado de segurança.

\section{CONCLUSÃO}

A necessidade das alterações constitucionais para ajustes no sistema de Previdência Social brasileira não autoriza a eliminação dos fundamentos constitucionais da segurança jurídica, da segurança social, da boa-fé, da confiança legítima, do direito expectado, da proporcionalidade e da razoabilidade, que devem estar presentes mesmo na mobilidade e na alteração normativo constitucional.

Nestes termos, as reformas constitucionais da Previdência Social brasileira devem trazer no seu bojo normas de transição que atendam aos parâmetros constitucionais, porquanto a justiça transicional é direito fundamental da pessoa humana, para que não se desproteja seus direitos expectados relativos ao tempo exercido e contribuído, bem como se adeque a sua situação em curso à nova realidade.

A ausência de tais normas implica em inconstitucionalidade por omissão, na mesma medida em que as regras de transição que agridam a segurança jurídica, a segurança social, a boa-fé, a confiança legítima, o direito expectado, a proporcionalidade e a razoabilidade, incorrem em inconstitucionalidade por ação.

A despeito de ser possível a superposição de normas constitucionais de transição, este fenômeno igualmente deve respeitar as garantias constitucionais da segurança jurídica, da

\footnotetext{
${ }^{6} \mathrm{CF}$, Art. $3^{\circ}$ Constituem objetivos fundamentais da República Federativa do Brasil: (...) IV - promover o bem de todos, sem preconceitos de origem, raça, sexo, cor, idade e quaisquer outras formas de discriminação. E, CF, art. $5^{\circ}$. Todos são iguais perante a lei, sem distinção de qualquer natureza, garantindo-se aos brasileiros e aos estrangeiros residentes no País a inviolabilidade do direito à vida, à liberdade, à igualdade, à segurança e à propriedade, nos termos seguintes [...]
} 
segurança social, da boa-fé, da confiança legítima, da proporcionalidade e da razoabilidade. A superposição que ofenda a estes preceitos incorre em evidente inconstitucionalidade.

Nesse cenário, ficou demonstrado que as superposições de normas constitucionais de transição na reforma da previdência social, especificamente do art. 17 da Emenda Constitucional $\mathrm{n}^{\circ} 103$ (BRASIL, 2019) sobre o art. 9०, da Emenda Constitucional $\mathrm{n}^{\circ} 20$ (BRASIL, 1998) e do art. 20, da Emenda Constitucional n 103 (BRASIL, 2019) sobre o art. $2^{\circ}$, da Emenda Constitucional n 41 (BRASIL, 2003), são nitidamente inconstitucionais.

A uma, porque a majoração do pedágio de $20 \%$ para $50 \%$ no caso do Regime Geral de Previdência Social e de 20\% para 100\% no caso do Regime Próprio de Previdência Social cria insegurança jurídica e social, atenta contra o direito exepectado, a boa-fé e a confiança legítima, sendo absurdamente desproporcional e sem o mínimo de razoabilidade.

A duas, porque trata de forma discriminatória a situação do segurado do Regime Geral de Previdência Social em relação à situação do segurado do Regime Próprio de Previdência Social, que originalmente não havia tratamento diferenciado e não houve justificativa posterior para essa discriminação negativa. De modo expresso, os arts. 17 e 20, da Emenda Constitucional n ${ }^{\circ} 103$ (BRASIL, 2019) fere o art. $3^{\circ}$, IV c/c art. $5^{\circ}$ e $6^{\circ}$ caput, ambos da Constituição (BRASIL, 1988).

O custo de se manter vigente essa inconstitucionalidade será o completo descrédito com as instituições da Previdência Social brasileira, que, a despeito de necessitar de reformas, precisa que as mesmas sejam feitas de acordo com as garantias constitucionais vigentes.

\section{REFERÊNCIAS}

ALEXY, Robert. Teoria de los derechos fundamentales. Madrid: Centro de Estúdios Constitucionales, 1993.

BRASIL. [Constituição (1988)]. Constituição da República Federativa do Brasil de 1988. Brasília, DF: Presidência da República, [2020]. Disponível em: http://www.planalto.gov.br/ccivil_03/Constituicao/Constituiçao.htm. Acesso em: 29 abr. 2020.

BRASIL. Decreto-Lei $n^{0}$ 4.657, de 4 de setembro de 1942: Lei de Introdução às normas do Direito Brasileiro. Brasília, DF: Presidência da República, [2020]. Disponível em: http://www.planalto.gov.br/ccivil_03/decreto-lei/del4657compilado.htm. Acesso em: 29 abr. 2020. 
BRASIL. [Constituição (1988)]. Emenda Constitucional no 3, de 17 de março de 1993. Brasília, DF: Presidência da República, [2020]. Disponível em:

http://www.planalto.gov.br/ccivil_03/constituicao/emendas/emc/emc03.htm. Acesso em: 29 abr. 2020.

BRASIL. [Constituição (1988)]. Emenda Constitucional no 20, de 15 de dezembro de 1998. Brasília, DF: Presidência da República, [2020]. Disponível em:

http://www.planalto.gov.br/ccivil_03/constituicao/emendas/emc/emc20.htm. Acesso em: 29 abr. 2020.

BRASIL. [Constituição (1988)]. Emenda Constitucional no 41, de 19 de dezembro de 2003. Brasília, DF: Presidência da República, [2020]. Disponível em:

http://www.planalto.gov.br/ccivil_03/constituicao/emendas/emc/emc41.htm . Acesso em: 29 abr. 2020.

BRASIL. [Constituição (1988)]. Emenda Constitucional no 47, de 5 de julho de 2005. Brasília, DF: Presidência da República, [2020]. Disponível em: http://www.planalto.gov.br/ccivil_03/constituicao/emendas/emc/emc47.htm. Acesso em: 29 abr. 2020.

BRASIL. [Constituição (1988)]. Emenda Constitucional no 70, de 29 de março de 2012. Brasília, DF: Presidência da República, [2020]. Disponível em:

http://www.planalto.gov.br/ccivil_03/constituicao/emendas/emc/emc70.htm. Acesso em: 29 abr. 2020.

BRASIL. [Constituição (1988)]. Emenda Constitucional no 88, de 7 de maio de 2015. Brasília, DF: Presidência da República, [2020]. Disponível em:

http://www.planalto.gov.br/ccivil_03/constituicao/emendas/emc/emc88.htm. Acesso em: 29 abr. 2020.

BRASIL. [Constituição (1988)]. Emenda Constitucional nº 103, de 12 de novembro de 2019. Brasília, DF: Presidência da República, [2020]. Disponível em:

http://www.planalto.gov.br/ccivil_03/constituicao/emendas/emc/emc103.htm. Acesso em: 29 abr. 2020.

BRASIL. Lei Federal $\mathbf{n}^{0}$ 13.954, de 16 de dezembro de 2019. Brasília, DF: Presidência da República, [2020]. Disponível em:

http://www.planalto.gov.br/ccivil_03/_ato2019-2022/2019/lei/L13954.htm. Acesso em: 29 abr. 2020.

BRASIL. Superior Tribunal de Justiça. Recursos Especial no 1424814/SP - São Paulo.

Relator: Ministro Marco Aurélio Belizze. Pesquisa de Jurisprudência, Acórdãos, 10 outubro de 2016c. Disponível em:

https://ww2.stj.jus.br/processo/revista/documento/mediado/?componente=ITA\&sequencial=1 543661\&num_registro=201304055559\&data=20161010\&formato=PDF. Acesso em: 29 abr. 2020.

Rev. de Direitos Sociais, Seguridade e Previdência Social | e-ISSN: 2525-9865 | Evento Virtual | v. 6 | n. 1 | p. 101-122 | Jan/Jun. 2020 
BRASIL. Superior Tribunal de Justiça. Recursos Repetitivo no ${ }^{\circ}$ 1063343/RS - Rio Grande do Sul. Relator: Ministro Nancy Andrighi. Pesquisa de Jurisprudência, Acórdãos, 16 novembro de 2009. Disponível em:

https://ww2.stj.jus.br/processo/revista/documento/mediado/?componente=ITA\&sequencial=8 74641\&num_registro $=200801289049 \&$ data $=20101116 \&$ formato=PDF. Acesso em: 29 abr. 2020.

BRASIL. Supremo Tribunal Federal. Ação direta de inconstitucionalidade n ${ }^{\circ}$ 907/RJ - Rio de Janeiro. Relator: Ministro Alexandre de Moraes. Pesquisa de Jurisprudência, Acórdãos, 24 novembro 2017a. Disponível em:

http://redir.stf.jus.br/paginadorpub/paginador.jsp?docTP=TP\&docID=14113979. Acesso em: 29 abr. 2020.

BRASIL. Supremo Tribunal Federal. Ação direta de inconstitucionalidade n ${ }^{\circ}$ 1724/RN - Rio Grande do Norte. Relator: Ministro Gilmar Mendes. Pesquisa de Jurisprudência, Acórdãos, 16 setembro 2019a. Disponível em:

http://redir.stf.jus.br/paginadorpub/paginador.jsp?docTP=TP\&docID=750833015. Acesso em: 29 abr. 2020.

BRASIL. Supremo Tribunal Federal. Ação direta de inconstitucionalidade no 3105/DF Distrito Federal. Relator: Ministro Cezar Peluso. Pesquisa de Jurisprudência, Acórdãos, 2 fevereiro 2007. Disponível em:

http://redir.stf.jus.br/paginadorpub/paginador.jsp?docTP=AC\&docID=408591. Acesso em: 29 abr. 2020.

BRASIL. Supremo Tribunal Federal. Ação direta de inconstitucionalidade $n^{\circ}$ 5468/DF Distrito Federal. Relator: Ministro Luiz Fux. Pesquisa de Jurisprudência, Acórdãos, 2 agosto 2017b. Disponível em:

http://redir.stf.jus.br/paginadorpub/paginador.jsp?docTP=TP\&docID=13269137. Acesso em: 29 abr. 2020.

BRASIL. Supremo Tribunal Federal. Agravo de Instrumento $n^{\circ}$ 727872/RS - Rio Grande do Sul. Relator: Ministro Roberto Barroso. Pesquisa de Jurisprudência, Acórdãos, 18 de maio de 2015a. Disponível em:

http://redir.stf.jus.br/paginadorpub/paginador.jsp?docTP=TP\&docID=8479282. Acesso em: 29 abr. 2020.

BRASIL. Supremo Tribunal Federal. Agravo Regimento no Recurso Extraordinário no 777574/PE - Pernambuco. Relator: Ministro Roberto Barroso. Pesquisa de Jurisprudência, Acórdãos, 22 de maio de 2015b. Disponível em:

http://redir.stf.jus.br/paginadorpub/paginador.jsp?docTP=TP\&docID=8479282. Acesso em: 29 abr. 2020.

BRASIL. Supremo Tribunal Federal. Habeas Corpus no 124306/RJ - Rio de Janeiro. Relator: Ministro Marco Aurélio. Pesquisa de Jurisprudência, Acórdãos, 9 de agosto de 2016a. Disponível em: 
http://redir.stf.jus.br/paginadorpub/paginador.jsp?docTP=TP\&docID=12580345. Acesso em: 29 abr. 2020.

BRASIL. Supremo Tribunal Federal. Recurso Extraordinário nº 640452/RO - Rondônia. Relator: Ministro Joaquim Barbosa. Pesquisa de Jurisprudência, Acórdãos, 6 de outubro de 2011. Disponível em:

http://redir.stf.jus.br/paginadorpub/paginador.jsp?docTP=TP\&docID=1609847. Acesso em: 29 abr. 2020.

BRASIL. Supremo Tribunal Federal. Recurso Extraordinário no 778889/PE - Pernambuco. Relator: Ministro Roberto Barroso. Pesquisa de Jurisprudência, Acórdãos, 1 de agosto de 2016b. Disponível em:

http://redir.stf.jus.br/paginadorpub/paginador.jsp?docTP=TP\&docID=11338347. Acesso em: 29 abr. 2020.

BRASIL. Supremo Tribunal Federal. Recurso Extraordinário n 958252/MG - Minas Gerais. Relator: Ministro Luiz Fux. Pesquisa de Jurisprudência, Acórdãos, 13 de setembro de 2019b. Disponível em:

http://redir.stf.jus.br/paginadorpub/paginador.jsp?docTP=TP\&docID=750817537. Acesso em: 29 abr. 2020.

CAMPOS, Marcelo Barroso Lima Brito de. Direitos previdenciários expectados: a proteção da relação jurídica previdenciária dos servidores públicos. Curitiba: Juruá, 2012.

CAMPOS, Marcelo Barroso Lima Brito de. Manual dos Servidores Públicos. São Paulo: Lujur, 2010.

DERZI, Misabel de Abreu Machado. Justiça prospectiva no Imposto de Renda. Revista Internacional de Direito Tributário. Belo Horizonte: Del Rey, v. 5, p. 163-202, jan./jun. 2006.

FERREIRA, Aurélio Buarque de Holanda. Mini Aurélio: o dicionário da língua portuguesa. 8. ed. Curitiba: Positivo, 2010.

FIGUEIREDO, Lúcia Valle. Curso de direito administrativo. São Paulo: Malheiros, 2003.

MIRANDA, Francisco Cavalcanti Pontes de. Tratado de direito privado: parte geral. Rio de Janeiro: Borsoi, 1955. t. 5.

SOUZA, Victor. Proteção e promoção da confiança no Direito Previdenciário. Curitiba: Alteridade, 2018. 